\title{
Nomenclatural Novelties in the Orchidaceae from Venezuela and Guyana
}

\author{
Germán Carnevali Fernández-Concha ${ }^{1}$ and Ivón M. Ramírez-Morillo \\ Herbario CICY, Centro de Investigación Científica de Yucatán, A.C., A.P. 87, Cordemex, \\ Mérida 97310, Yucatán, México. carneval@cicy.mx, ramirez@cicy.mx
}

Abstract. The following represent new specific taxa in the Orchidaceae from Venezuela: Epidendrum cesar-fernandezii Carnevali \& I. Ramírez, E. reclinatum Carnevali \& I. Ramírez, Pleurothallis loreae Carnevali \& I. Ramírez, P. escalerensis Carnevali \& C. A. Luer, and P. stellata I. Ramírez \& Carnevali. A new nothospecies, Epidendrum $\times$ gransabanensis Carnevali \& I. Ramírez, is proposed as the product of the introgression between Epidendrum ibaguense HBK and E. secundum Jacquin. A new subspecies, Liparis nervosa subsp. granitica Carnevali \& I. Ramírez, is proposed to accommodate populations of Liparis nervosa (Thunberg) Lindley restricted to granitic outcrops in the northwestern Guayana in Venezuela. Descriptions, illustrations, and discussions of affinities are provided for the newly proposed taxa.

Key words: Epidendrum, Guyana, Liparis, Orchidaceae, Pleurothallis, Venezuela.

Field and herbarium studies of Venezuelan Orchidaceae relevant to several floristic projects, primarily the treatment for the Flora of the Venezuelan Guayana project (Carnevali et al., 2003), have uncovered several new taxa. These orchid taxa are herein proposed as new.

\section{SUBTRIBE LAELIINAE}

Epidendrum cesar-fernandezii Carnevali \& I. Ramírez, sp. nov. TYPE: Venezuela. Táchira: along road between Rubio and Delicias, $25 \mathrm{~km}$ above Rubio, SW of Rubio, 23 Aug. 1976, T. Croat \& G. Bunting 38489 (holotype, VEN; isotype, MO, isotype fragment, CICY). Figure 1.

Species haec Epidendro goodspeediano A. D. Hawkes similis sed floribus multiminoribus; E. agoyanense et $E$. aguaricoense affinis sed ovario sepaloque verruculosis differt; E. densifloro affinis sed labello latiore, petalis pendulis recedit.

Epiphytic herbs, to $2 \mathrm{~m}$ tall; roots unknown; stems simple, multifoliate, slightly compressed, to
$15 \mathrm{~mm}$ thick near apex; apical leaves $12-17 \mathrm{~cm}$ long, 15-25 mm wide, elliptic, acute, acuminate, margin entire; sheaths 5-6 cm long, tubular, smooth; inflorescence 35-55 cm long, terminal on the mature stem without a spathe, flowering once, paniculate, the primary branches pinnate again in the lower $1 / 4$ of their length; peduncle $2-4 \mathrm{~cm}$ long, subterete or slightly compressed, surface smooth in the lower $1 / 3$, becoming laxly verruculose above; primary branches $25-30 \mathrm{~cm}$ long, secondary branches $3-5.5 \mathrm{~cm}$ long bearing 5 to 8 flowers; bracts of the peduncle $8-11 \mathrm{~cm}$ long, ca. $1 \mathrm{~cm}$ wide at base, very narrowly triangular and acuminate, bracts of the primary branches similar to those of peduncle but much smaller, 3-5 cm long; rachis on the branches subterete and slightly angulate, laxly verruculose; floral bracts $3.8-4.1 \mathrm{~mm}$ long, ca. $1 \mathrm{~mm}$ wide, narrowly triangular; flowers resupinate, relatively small for the group; sepals green, suffused with honey brown on the apical half, petals translucent green, the labellum white, suffused with pink and some areas with a green hue around the edges of the callosities, column pale pink on the apical half, the basal half dull dark green with dull maroon tinges dorsally and where it joins the lateral sepals; sepals widely spreading, fleshy, slightly concave along the midnerve on the apical half, dorsally conspicuous and coarsely verruculose; dorsal sepal 11-12 × 2.8-3.1 mm, elliptic spathulate, obtusely acute, 5-nerved; lateral sepals 9-11 $\times 3.5-4 \mathrm{~mm}$, elliptic spathulate, obtusely acute, 6-nerved, subapically with fleshy, conical, acute mucro $1 \mathrm{~mm}$ long; petals $9.8-10.2 \mathrm{~mm}$ long, $0.9 \mathrm{~mm}$ wide at apex, $0.3 \mathrm{~mm}$ wide at the base, thin, flexed downward and pendent behind the lateral sepals, 1nerved, filiform-oblanceolate, rounded to broadly obtuse at apex, margin entire; labellum 5.9-6.1 $\times$ $8.9-9.2 \mathrm{~mm}$ across the forcefully spread lateral lobes, convex in natural position, fused up to the apex of the column, the margins finely fimbriate, in general outline transversely oblong elliptic, apically conspicuously but shallowly emarginate, the disk

${ }^{1}$ Author to whom reprint requests should be addressed. 


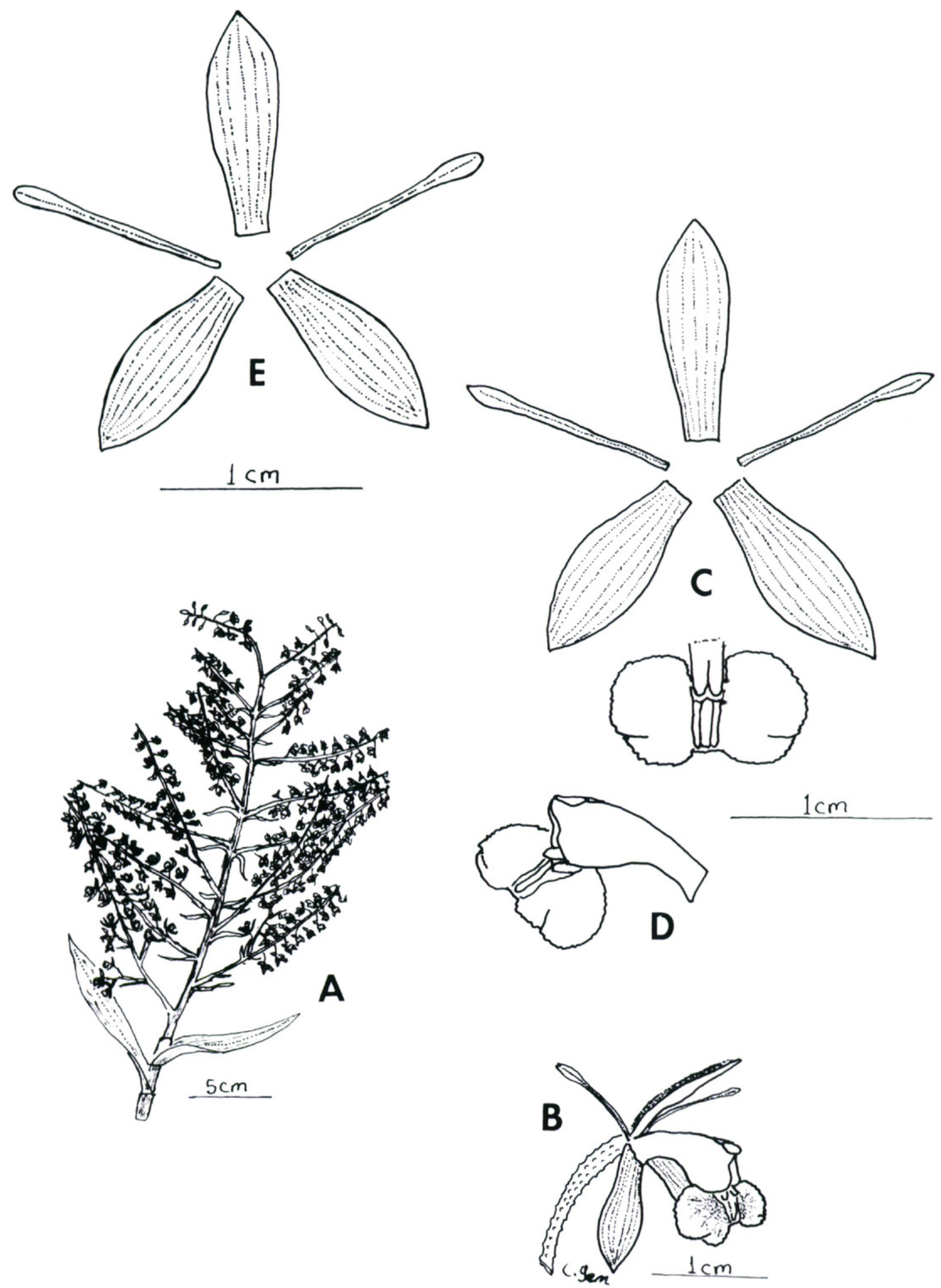

Figure 1. Epidendrum cesar-fernandezii Carnevali \& I. Ramírez. - A. Habit. - B. Flower in natural position. - C. Floral parts, flattened with labellum. - D. Column and labellum. - E. Floral parts flattened showing different petal shape. (Based on isotype, T. Croat \& G. Bunting 38489, MO.) Drawing by Carlos Yam. 



$4 \mathrm{~cm}$

Figure 2. - A. Epidendrum ibaguense (based on Carnevali et al. 3241, VEN; 70\% EtOH CICY). -B. Epidendrum $\times$ gransabanensis Carnevali \& I. Ramírez (based on Carnevali et al. 3239, VEN; 70 \% EtOH CICY). - C. Epidendrum secundum (based on Carnevali et al. 3240, VEN; 70\% EtOH CICY). Drawings by Bruno Manara.

bicallose, with 3 prominent blunt keels that run up to the apex of the labellum, the one in the middle thicker and higher; the whole blade 4-lobed, the basal lobes 4.4-4.6 mm long, reniform, basally cordate, the apical lobes ca. $3.5 \mathrm{~mm}$ long, ca. $2 \mathrm{~mm}$ wide, transversely reniform or subquadrate, the apices diverging, the basal margins separated from the basal lobes by very narrow sinuses or fused to them; column 7.5-8 mm long including the clinandrium, ca. $3.5 \mathrm{~mm}$ thick at apex; clinandrium obsolete, margin entire; anther ca. $2 \mathrm{~mm}$ long, ovoid-subspheric, 4-locular, pollinia 4 of the "bird-wing" type, strongly compressed laterally, the inner ones somewhat smaller and partially fused on their ventral surface, caudicles smooth, soft, viscidium transparent; rostellum subapical, cleft, nectary shallow.

Etymology. The specific epithet refers to César Fernández, a collector of the paratype of the species and an active researcher of the Venezuelan Andean orchid flora. The hyphen in the epithet is to be maintained, according to Article 60.9 of the ICBN (Greuter et al., 2000).

This new species is similar to Epidendrum densiflorum Hooker, but the labellum is proportionally wider, the margins are more erose, and the ovary and outer faces of the sepals are more verruculose. The petals are pendulous in the new species whereas they are spreading in $E$. densiflorum. The large plants and the general structure of inflorescences and flowers suggest an affinity with the Ecuadorian Epidendrum agoyanense Hágsater \& Dodson and E. aguaricoense Hágsater \& Dodson, but these spe- cies, also from the eastern Amazonian slopes of the Andes, feature labella with entire margins and much more divaricate apical lobes. Epidendrum goodspeedianum, from the western Andes, is also similar but it is a much larger plant and has larger flowers than E. cesar-fernandezii, with the labellum more than $2.5 \mathrm{~cm}$ wide and pedicels of up to $6 \mathrm{~cm}$ long.

Paratype. VENEZUELA. Táchira: Mun. Junín, El Playón, 1115 m, 3 Aug. 2001, C. Fernández 0341 (VEN).

Epidendrum $\times$ gransabanensis Carnevali \& I. Ramírez, nothospecies nov. TYPE: Venezuela. Bolívar: road El Dorado-Santa Elena de Uairén, km $138 \mathrm{~S}$ of El Dorado, Canaima National Park, NE Gran Sabana general area, approx. $6^{\circ} 19^{\prime} \mathrm{N}, 61^{\circ} 25^{\prime} \mathrm{W}$, shrublands over sandy soils along the road, in a mixed mosaic along with gallery forests, sandstone outcrops, and boggy associations, $1500 \mathrm{~m}, 3$ Aug. 1993, G. Carnevali, F. Lorea, N. Warford, B. Whitlock, R. Rivero, W. Díaz \& C. Fleming 3238 (holotype, VEN; isotype, CICY [70\% EtOH]). Figure 2.

Hybrid formula: Epidendrum ibaguense HBK $\times$ Epidendrum secundum Jacquin.

Nothospecies intermedia quam Epidendrum ibaguense et E. secundum; haec Epidendro ibaguensi similis sed floribus non resupinatis, sepalis petalisque proportione latiore brevioribus, callo crassiore, columna breviore recedit.

Terrestrial herbs; growing over sandy soils, sunloving; stems, leaves, and inflorescences indistinguishable from those of Epidendrum ibaguense, flowers non-resupinate or rarely resupinate, petals 
and sepals widely spreading, purple, labellum purple with a yellow callus; dorsal sepal 11.5-12.5 $\times$ 3.1-3.5 mm, narrowly elliptic, acute; lateral sepals $12-13 \times 3.7-4 \mathrm{~mm}$, elliptic, oblique, acute; petals $10-11 \times 2.3-2.8 \mathrm{~mm}$, narrowly elliptic, acute; labellum cordiform in general outline, with the margins irregularly dentate to erose or even laciniate, flat, 7.5-8 mm long from the apex of the column, 3-lobed, 13.5-14 mm wide across the apices of the lateral lobes; central lobe 3.7-4 × 8.5-8.7 mm, broadly obovate, apically emarginate; lateral lobes reniform, 0.5-0.66 mm long and wide, flabellate obovate; disk with a pair of laminar, obovate calli at each side of the apex of the column and that can be interpreted as being a continuation of it, and a laminar keel running down the center; column straight, 0.55-0.65 mm long.

This new entity is almost certainly the result of the introgression of Epidendrum ibaguense and E. secundum. Both taxa grow on rocky, exposed places, in a landscape of a mixed mosaic of savanna with gallery forests over sandy, acidic soils along the road from El Dorado to Santa Elena de Uairén, the former at low elevations $(800-1000 \mathrm{~m})$, the latter at relatively higher elevations $(1000-1300 \mathrm{~m})$. Mixed populations of both parental taxa and the hybrid taxon are common at intermediate altitudes. Epidendrum $\times$ gransabanensis was treated as Epidendrum ibaguense $\times$ Epidendrum secundum in Carnevali and Ramírez (in Carnevali et al., 2003: 338).

Epidendrum ibaguense and related taxa, e.g., E. splendens Schlechter, E. radicans Lindley, E. macrocarpum Richard, E. calanthum Reichenbach f. $\&$ Warscewicz, and others, are characterized by resupinate flowers and a simple callus consisting of two laminar projections at each side of the apex of the column often joined with two small, globular or obovate-laminar, keel-like calli at the base of the disk, and a central laminar keel running down the center, rarely to the apex of the emargination of the central lobe, but more often ending midway along the isthmus of the central lobe. This thin laminar keel frequently curves or waves one way or the other. The column is usually relatively long, as long as or longer than the blade of the labellum. The perianth segments are of a relatively soft texture. A few taxa of this complex, e.g., E. mimeticum Carnevali \& G. Romero, E. flexuosum G. Meyer, and clones of E. radicans, consistently feature non-resupinate flowers, but are otherwise clearly members of this grouping when other morphological traits (e.g., callus, labellum, and perianth segment shape) are taken into account.
On the other hand, members of the extremely difficult Epidendrum secundum complex, e.g., E. catillus Reichenbach f. \& Warscewicz, E. elongatum Jacquin, E. jamesonii Lindley, E. tricallosum Schlechter, etc., feature non-resupinate flowers and a complex callus composed of several to many tubercles and thick, intertwined keels, and a relatively short column, usually shorter than the labellum blade and much shorter than the petals and sepals. Further, the lateral lobes of the labellum appear to originate from the sides of the apex of the column, not from an independent, free, laminar blade, as is the case in the labella found in the members of the E. ibaguense complex. Good illustrations of members of this complex (probably several species on the same plate) are to be found in Dunsterville and Garay (1979: 224, plate 187) as E. elongatum. Good color photographs of members of the E. ibaguense and the E. secundum complexes of the Guayana are found in Couret (1982) and Romero (1997). In this paper, we follow the approach taken by Carnevali and Ramírez (in Carnevali et al., 2003: 342-343) in treating most members of this complex as a single entity, Epidendrum secundum. The group of taxa around E. secundum requires an urgent revision to ascertain their boundaries and distributions. In the meantime, it is safest to treat them as a single, widely ranging, and variable species.

Within the mixed population in the general Gran Sabana area in Venezuela mentioned above, colonies of plants that are intermediate between species of the two complexes are commonly found. On occasion, isolated plants featuring intermediate combinations of characters are also encountered in a landscape of a mixed mosaic of savanna with gallery forests. These putative hybrid plants are characterized by non-resupinate flowers (reminiscent of E. secundum parentage) and a simplified callus (from the E. ibaguense parentage) consisting of two thick lateral calli following the lateral, apical edges of the column, and a laminar keel running down the center. This laminar keel is thicker and proportionally shorter than those found in the members of the Epidendrum ibaguense complex.

The two specimens cited in this protologue represent two extremes in labellum shape variation within the nothospecies, though both display nonresupinate flowers. The holotype corresponds to an individual showing an E. ibaguense-type labellum, which is, however, somewhat broader and shorter. On the other hand, Figure 2B depicts a second plant of this grex (G. Carnevali et al. 3239), which features a more $E$. secundum-like labellum, but with simplified calli. Both were collected along the 
El Dorado-Santa Elena de Uairén road growing within a perimeter of a couple of meters and along with many other plants showing various combinations of parental characters. Populations of both $E$. ibaguense and E. secundum, both in pure stands or in mixed communities, were found nearby. We decided to name these apparent hybrids since they are a common sight along the road and are becoming increasingly common in both herbarium and live collections. The introgression between the two species in the general Gran Sabana area is apparently associated with disturbed, anthropogenic conditions. This situation has probably created novel microhabitats for the survival of the hybrids, or more likely, has somehow allowed for the breakdown of former pollination barriers between members of the E. ibaguense and E. secundum populations. A more thorough sampling program is required to ascertain whether the introgression process is restricted to disturbed areas close to roads or human settlements, or if it occurs elsewhere, under more pristine conditions.

An additional taxon, recently described as a species, but not mentioned as a nothospecies, is probably also the result of the introgression of members of the Epidendrum ibaguense and E. secundum complexes. This is Epidendrum thermophilum Hágsater \& Dodson (Hágsater \& Dodson, 1993) from northwestern Ecuador. This entity features non-resupinate, small red-purple flowers with the overall morphology of an intermediate between the two complexes. The labellum is shallowly 3 -lobed with the simpler callus of the E. ibaguense complex. Epidendrum calanthum (a member of the E. ibaguense complex with small, pink, soft-textured flowers with an almost simple labellum) grows nearby, and some members of the E. secundum complex must occur in the immediate neighborhood, since populations of these species (such as E. jamiesonis Reichenbach f.) are locally common in open places in the Andean slopes, e.g., D. Rubio \& C. Quelal 692, MO). It would appear that non-resupination is a dominant feature in hybrids involving members of both complexes.

Paratype. VENEZUELA. Bolívar: locality same as the holotype, G. Carnevali et al. 3239 (VEN, CICY $[\mathrm{EtOH}])$.

Epidendrum reclinatum Carnevali \& I. Ramírez, sp. nov. TYPE: Guyana. Mazaruni-Potaro: Guyana-Venezuela border area, Roraima summit, la Proa Camp, E of border, near Lake Gladys, mostly open rocky areas with ravines and lake, $5^{\circ} 15^{\prime} 36^{\prime \prime} \mathrm{N}, 60^{\circ} 13^{\prime} 00^{\prime \prime} \mathrm{W}, 2800 \mathrm{~m}, 14$ Apr. 1988, R. Liesner 23315 (holotype, VEN; isotypes, CICY, MO). Figures 3, 4.

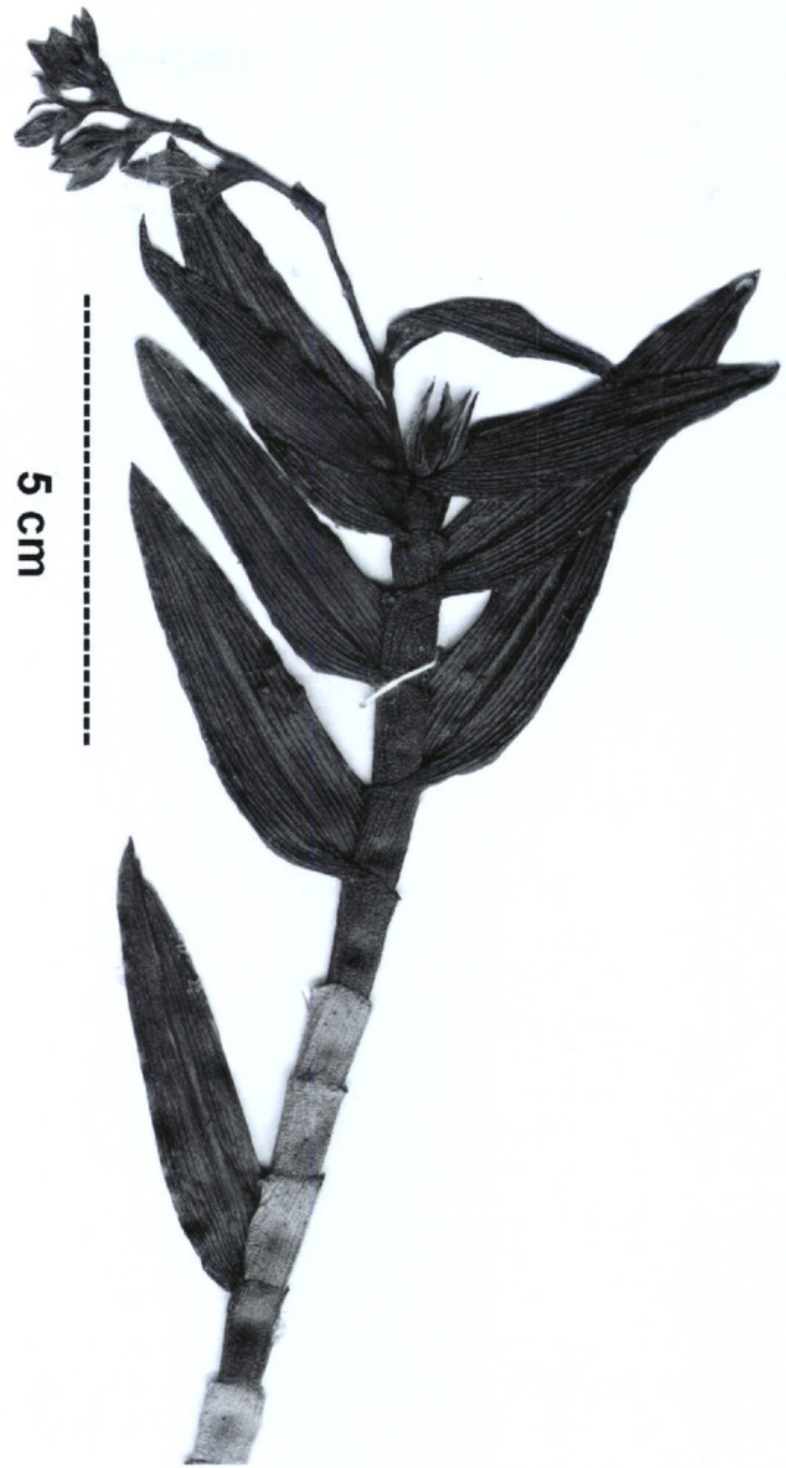

Figure 3. Epidendrum reclinatum Carnevali \& I. Ramírez. Habit (based on F. Delascio-Chitty 13972, VEN; digital scan by Germán Carnevali).

Species haec Epidendro montigeno similis sed plantis prostratis, bracteis majoribus, floribus albidis vel flavidis, petalis proportione latioribus recedit.

Terrestrial herbs, prostrate, sprawling and creeping, growing on grassy or boggy areas, drying dark brown to black with an oily sheen; roots carnose, 1-2 mm thick; stems (7-)10-20(-35) cm long, 0.4$0.6 \mathrm{~mm}$ thick, totally clothed by sheaths; rooting at the base and above as it sprawls over the substrate; foliose from the base when young, eventually leaves restricted to the upper half or third of the stem, simple at first, then branching after flowering; branches occurring at several levels on the stems, often about mid-length of the flowering stem, 7-13 $\mathrm{cm}$ long; leaves $3.5-5 \mathrm{~cm}$ long, $8-11 \mathrm{~mm}$ wide on flowering stems, smaller on young stems or branches, narrowly ovate, acute to subacuminate, margins revolute, minutely erose toward the apex, entire 

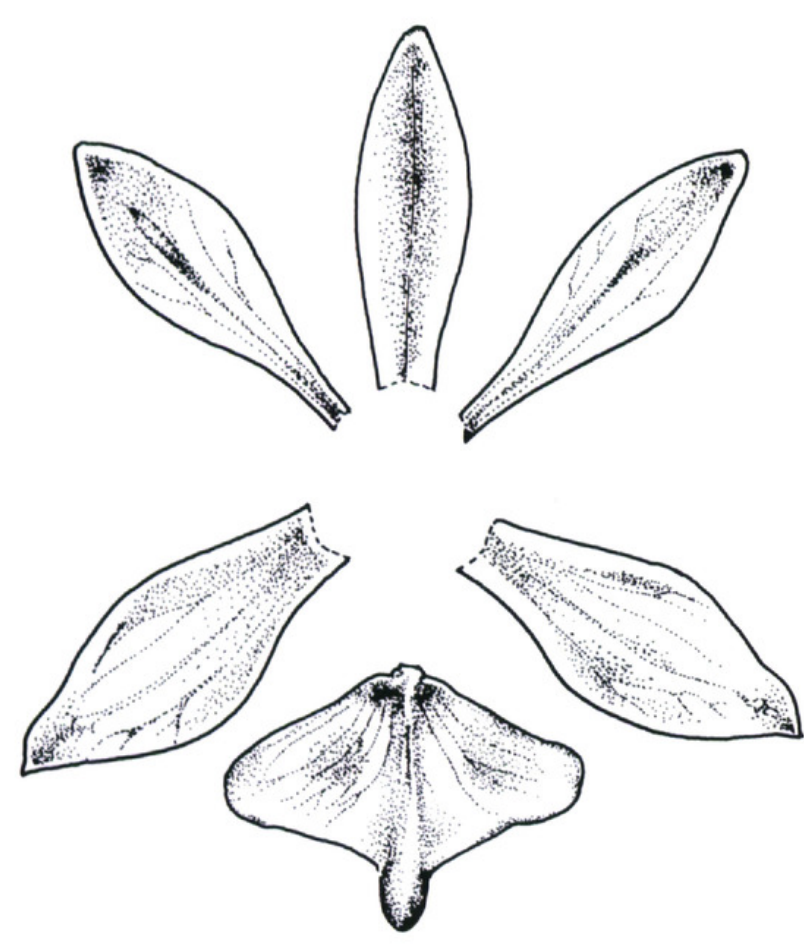

$\mathrm{Icm}$

Figure 4. Epidendrum reclinatum Carnevali \& I. Ramírez. Floral parts flattened (based on holotype, $R$. Liesner 23315 , VEN). Drawing by Rossana Marrufo.

elsewhere; blades articulate with their sheaths, conspicuously striate and minutely cross-veined in dry material, all in one plane, sheaths $10-20 \mathrm{~mm}$ long, tubular, scarious, rugulose; inflorescences terminal from the main stems or the branches, racemose, $3-$ $7 \mathrm{~cm}$ long, 6- to 8-flowered, lacking a spathe; peduncle $2.5-3 \mathrm{~cm}$ long; rachis $3-4 \mathrm{~cm}$ long, erect or apparently nutant; floral bract $6-9 \times 3-5 \mathrm{~mm}$, surpassing the pedicellate ovary at anthesis, cucullate, fleshy; flowers white or yellow-tinged, fleshy, apparently non-resupinate; pedicellate ovary 4-5 mm long; sepals concave, fleshy, dorsal sepal 7-8 × 2.5-2.7 mm, elliptic-oblong, obtuse, dorsally keeled, 3- to 5-nerved; lateral sepals 7.9-8.1 $\times$ 4-4.5 mm, broadly elliptic, oblique, obtusely acute margins concave, erose particularly toward the apex, 3- to 5-nerved; petals $6.5-8 \times 2.1-2.6 \mathrm{~mm}$, narrowly spathulate, elliptic, apically broadly obtuse to subacute, margins erose, 1- to 3-nerved; labellum fleshier than other perianth segments, entire, deeply concave in natural position, fused to the column to its apex, the free portion $8-9 \mathrm{~mm}$ long from the insertion of the sepals and labellum, 6.5-8 mm wide when forcefully spread, transversely rhombic, the apex very fleshy, obtuse-acuminate, $1.2-1.5 \mathrm{~mm}$ long; column $3.5-4 \mathrm{~mm}$ long, ca. 2.5 $\mathrm{mm}$ thick, the clinandrium and anther smooth.
Epidendrum reclinatum is one of several taxa in the Epidendrum dendrobioides Thunberg complex, a group of taxa that has undergone extensive diversification in the Guayana Highlands, although several species of the group grow elsewhere. The complex is characterized by its mainly terrestrial or lithophytic habit (often at high elevations), usually on exposed, rocky or boggy conditions, the stems usually branching about mid-length, the fleshy flowers that are often campanulate, the relatively large, fleshy floral bracts, and the simple, deeply concave, often unspreadably fleshy labellum. Among other taxa in the complex, E. reclinatum is readily recognized by the prostrate, sprawling stems and short unbranched inflorescences. It is apparently most closely related to the sympatric or parapatric Epidendrum montigenum G. S. Ridley ex Oliver, with which it shares the softly fleshy flowers, the labellum being spreadable (though somewhat forcefully) in herbarium material. It is, however, easy to distinguish from that taxon by its white or yellowish flowers (vs. pink), the prostrate habit, the broader petals, and the more transverse labellum. This species was treated in Carnevali and Ramírez (in Carnevali et al., 2003: 345) as Epidendrum sp. A.

Several taxa in this complex are found sympatrically or parapatrically in the Roraima-Tepui massif, where $E$. reclinatum seems apparently restricted. Among these, Epidendrum alsum G. S. Ridley, E. montigenum, and this new taxon are endemic there. The several taxa of the Epidendrum dendrobioides complex occurring in the Venezuelan Guayana can be distinguished with the use of the following key.

Key to the Members of the EPIDEndRum dendrobioIdes Complex of the Venezuelan Guayana

1. Inflorescences shorter than the leaves; labellum longer than wide . . . . . . E. imthurnii Ridley

$1^{\prime}$. Inflorescences longer than the leaves; labellum as broad as or broader than long . . . . . . . . .

2(1). Flowers pale to deep pink; labellum fleshy coriaceous, flexible and thus easily flattened, thicker toward base . . . . . . E. E. montigenum

$2^{\prime}$. Flowers green, yellowish or cream-colored; labellum very fleshy (rarely fleshy coriaceous in E. reclinatum), rigid and impossible to flatten without breaking it, thicker toward the apex . .

$3(2)$. Plants prostrate, sprawling and creeping over boggy substrate; plants apparently restricted to Roraima tepui and surrounding massifs (Ilú Tepui, Kukenán Tepui) ......... E. reclinatum

3'. Plants erect, rarely weakly prostrate over shrubs on tepui shrublands; plants of many places in the Guayana Highlands . . . . . . .

4(3). Floral bracts $9-13 \mathrm{~mm}$ wide (since they are 
conduplicate, the width of one half can be doubled for easy measurement) $\ldots \ldots \ldots \ldots \ldots$ 4'. Floral bracts $3-7(-8) \mathrm{mm}$ long . . . . . . .

5(4). Floral bracts $3-4$ times longer than the pedicellate ovary ...... E. urbanianum Cogniaux

5'. Floral bracts shorter, up to 2 times longer than the pedicellate ovary ............

6(5). Inflorescences strictly erect, unbranched; rachis straight; leaves acute; floral bracts with straight apices; dorsal sepal 11-12 mm long; petals 10-12 mm long; plants from Cerro de La Neblina . . . . . . . . . . . . . . . . E. commelinispathum Carnevali \& I. Ramírez

6'. Inflorescences arching, decurving or pendent, often branching; rachis zigzag; leaves obtuse; dorsal sepal 6-7 mm long; petals $4.5-5.5 \mathrm{~mm}$ long; plants from Roraima and neighboring tepuis ........... E. alsum G. S. Ridley

7(5). Dorsal sepal 5-7 mm long, 1.9-2.1 mm wide; labellum 4-4.5 mm long, 6-7 mm wide ... . ................ E. durum Lindley

7'. Dorsal sepal 8-9 mm long, 4-4.5 mm wide; labellum $5-5.5 \mathrm{~mm}$ long, $7.5-9 \mathrm{~mm}$ wide ... ................ E. ulei Schlechter

Paratypes. VENEZUELA. Bolívar: Roraima, NE sector, Lago Gladys, 2700 m, 3-5 Apr. 1989, F. DelascioChitty 13972 (VEN); Ilú-tepui, lower plateau, 2500 m, 16 Apr. 1988, “. . . sterile, decumbent spreading . . , " $R$. Liesner 23431 (CICY, MO, VEN); Kukenán Tepui summit, 17 Apr. 1988, R. Liesner 23452 (MO, VEN).

\section{Tribe Malaxideae}

Liparis nervosa (Thunberg) Lindley, Gen. Sp. Orch. Pl. 26: 1830. Ophrys nervosa Thunberg ex Murray, Syst. Veg. (ed. 14): 814. 1784. TYPE: Japan. Thunberg s.n. (UPS not seen).

Liparis nervosa is widespread in the Neotropics and tropical Africa and Asia. For such a widespread taxon there seems to be little variation in flower shape. However, there is much vegetative variation, and some forms might merit subspecific recognition. One such distinctive series of populations is here treated at the subspecific level. Another set of Guianas plants with different floral coloration is discussed here in relation to the other subspecific taxa considered.

Liparis nervosa subsp. granitica Carnevali \& I. Ramírez, subsp. nov. TYPE: Venezuela. Bolívar: $1 \mathrm{~km} \mathrm{~S}$ of Quebrada La Flore, affluent of Río Ore, affluent of Río Parguaza, 85 m, 9 Sep. 1985, Julian A. Steyermark, Bruce Holst \& Bruno Manara 131667 (holotype, VEN; isotype, MO). Figure 5.

Species haec Lipari nervosae subsp. nervosae affinis sed plantis et floribus minoribus, foliis angustioribus, acutis, habito graniticola recedit.

Lithophytic, growing on cracks of rocks on ver-


Figure 5. Liparis nervosa subsp. granitica Carnevali \& I. Ramírez. Floral parts flattened (based on Julian A. Steyermark et al. 131667, VEN). Drawing by Rossana Marrufo.

tical granite walls. Pseudobulbs ovoid, 1-2 cm long, entirely concealed in shredded-nerved formless bracts; leaves 2(to 4) per pseudobulb, narrow to rarely wide-elliptic to ovate-elliptic, acute, basally attenuate into a pseudopetiole; laminae with 5 longitudinal nerves, prominent, (3-)5(-8) cm long, (1.6-)2.9(-3.9) cm wide, membranaceous, pale yellow-green, usually erect. Inflorescence terminal, erect to pendulous, apical, 8-14 cm long, a raceme, usually 3 -flowered to rarely 9-flowered; peduncle pinkish (fide Steyermark et al. 131667). Flowers small as compared to other members of the species, yellow (fide Steyermark et al. 131667), arranged from the mid-point to the apex of the inflorescence. Sepals and petals membranaceous, labellum curved backward. Sepals oblong, $7 \times 3 \mathrm{~mm}$, with 5 nerves, apically oblique, rounded, margins entire. Petals narrowly elliptic, apically rounded, $9 \times 2 \mathrm{~mm}$, margins entire. Labellum 2-lobed, in general shape obovate, strongly decurved, $5.1 \mathrm{~mm}$ long, $4.1 \mathrm{~mm}$ wide, apically notched, with a small mucro, 5nerved, three central and two lateral from where reticulate nerves expand to the margins, margins crenulate, with a $1.5 \mathrm{~mm}$ claw at the base of labellum from which two small $(0.5 \mathrm{~mm}$ long) apical horn-like calli project. Column strongly incurved 
apically, $4.5 \mathrm{~mm}$ long, with two small wings, 0.4 $\mathrm{mm}$ long.

Paratype. VENEZUELA. Amazonas: Mun. Atures, carretera Pto. Ayacucho-Samariapo, km 12.5, 100-150 m. 29 July 1993, A. Gröger 1034 (MO, VEN).

This entity is known from few collections and grows in seasonally dry areas in environments that are usually much drier than those where the typical subspecies for Liparis nervosa grows. It was treated as Liparis nervosa subsp. A in Carnevali and Ramírez (in Carnevali et al., 2003: 413). Although similar to the typical subspecies, the plants of the new subspecies are smaller (see key below), and the leaves are narrower ((1.6-)2.9(-3.9) cm vs. usually more than $4 \mathrm{~cm}$ in the typical subspecies) and dry a distinctive pale yellow-green or pale yellowbrown color. The inflorescence is also proportionally shorter. The flowers are somewhat smaller (dorsal sepal up to $7 \mathrm{~mm}$ long as opposed to ca. $8 \mathrm{~mm}$ in the typical subspecies) but otherwise identical to those of the typical subspecies. More material may indicate that this entity should be recognized at the species level. This new subspecies is locally abundant on granitic outcrops in northern Amazonas State and northwestern Bolívar State in Venezuela (possibly ranging into neighboring Colombia). There it grows on shady, rocky vertical walls or otherwise under the shade of shrubs. On the other hand, the typical subspecies is usually found growing on soil, often in boggy places or as subepiphytes in extremely humid places and not in dry, rocky places.

Liparis nervosa f. kappleri (Reichenbach f.) Christenson \& Carnevali, Lindleyana 11: 17. 1996. Sturmia kappleri Reichenbach f., Linnaea 22: 833. 1849. Leptorchis kappleri (Reichenbach f.) Kuntze, Revis. Gen. Pl. 671. 1891. Liparis kappleri (Reichenbach f.) Reichenbach f., Ann. Bot. Syst., 6: 218. 1864. TYPE: Surinam. Feb.-Apr. 1844, Kappler 1491 (MO).

This entity is rare and so far only known from the type collection (Christenson, 1996). However, since it is likely to appear elsewhere in the Guianas and the Venezuelan Guayana, we have included it in this account. It seems to be nothing more than an anthocyanin-free form of this species (Christenson, 1996). Liparis nervosa f. kappleri seems to be a distinctive morph of the typical subspecies, and should stand as a good taxon. However, more material may indicate closer affinities with subspecies granitica than with the type of the species.
The following key allows the identification of the infraspecific taxa of $L$. nervosa in the Guianas.

KEY TO THE INFRASPECIFIC TAXA OF LIPARIS NERVOSA IN THE GUiAnas

la. Leaves (3-)5(-8) cm long, (1.6-)2.9(-3.9) cm wide, usually narrowly elliptic, membranous, pale yellow-green upon drying; inflorescences 8$14 \mathrm{~cm}$ long ....... L. nervosa subsp. granitica

lb. Leaves usually longer than $8 \mathrm{~cm}$ in mature plants, often $10-30 \mathrm{~cm}$ long, usually broader than $4 \mathrm{~cm}$, often to $10 \mathrm{~cm}$ wide; usually elliptic, of a firmer texture, drying greenish or brownish; inflorescences (7-) $10-30(-50) \mathrm{cm}$ long; leaves drying several shades of brown ........

L. nervosa subsp. nervosa 2a. Flowers tinged with purple or brown ...

$$
\text { ............. L. nervosa f. nervosa }
$$

2b. Flowers entirely greenish yellow .....

\section{L. nervosa f. kappleri}

\section{Subtribe Pleurothallidinae}

Pleurothallis loreae Carnevali \& I. Ramírez, sp. nov. TYPE: Venezuela. Falcón: Sierra de San Luis, Zambrano-Curimagua road, cloud forests over karst, 1300-1500 m, 9 Aug. 1993, G. Carnevali, F. Lorea, N. Warford, B. Whitlock \& F. Morillo 3263 (holotype, VEN; CICY [EtOH, flower]). Figure 6.

Species haec Pleurothalli chamae affinis, sed plantis floribusque minoribus, sepalis dorsalibus 3-nervis, labello profunde concavo abhorret; affinis $P$. cordatae sed sepalo dorsali proportione angustiore, labello concavo, petalis carnosioribus glabris recedit.

Lithophytic, sun-loving, cespitose herbs; rhizome abbreviated; stems erect, straight, terete, 11-19 cm long, with two sheaths shorter than internodes, the shorter one basal, the longer at stem mid-point, sheaths 1.5-3.2 cm long, margins entire; leaves $6.5-6.7 \times 2.9-3.2 \mathrm{~cm}$, coriaceous, ovate, basally cordate, basal lobes overlapping by $1.5 \mathrm{~mm}$, apically long attenuate, acute; inflorescences emerging from two fibrous sheaths, fascicles of 4 or 5 flowers, 1 or 2 open at a time; pedicels ca. $2 \mathrm{~mm}$ long; pedicellate ovary $2.5 \mathrm{~mm}$ long, slightly verrucose; flowers fleshy, resupinate, concave, basically deep wine-purple, the sepals marginally somewhat orange-yellow, the petals and labellum rich purplered; sepals concave, thick, the margins incurved and minutely verruculose; dorsal sepal $5.5 \mathrm{~mm}$ long, $3.5 \mathrm{~mm}$ wide when expanded, elliptic-oblong, obtuse, 3-nerved; lateral sepals totally connate into a synsepal $4.4-4.6 \times 6.4-6.6 \mathrm{~mm}$ when expanded, widely ovate in general outline, fleshy, with 6 nerves, apically notched; petals $3-3.1 \times 1.1-1.2$ $\mathrm{mm}$ when deliberately expanded, thickly fleshy and concave, narrowly elliptic, acute, falcate, margins 

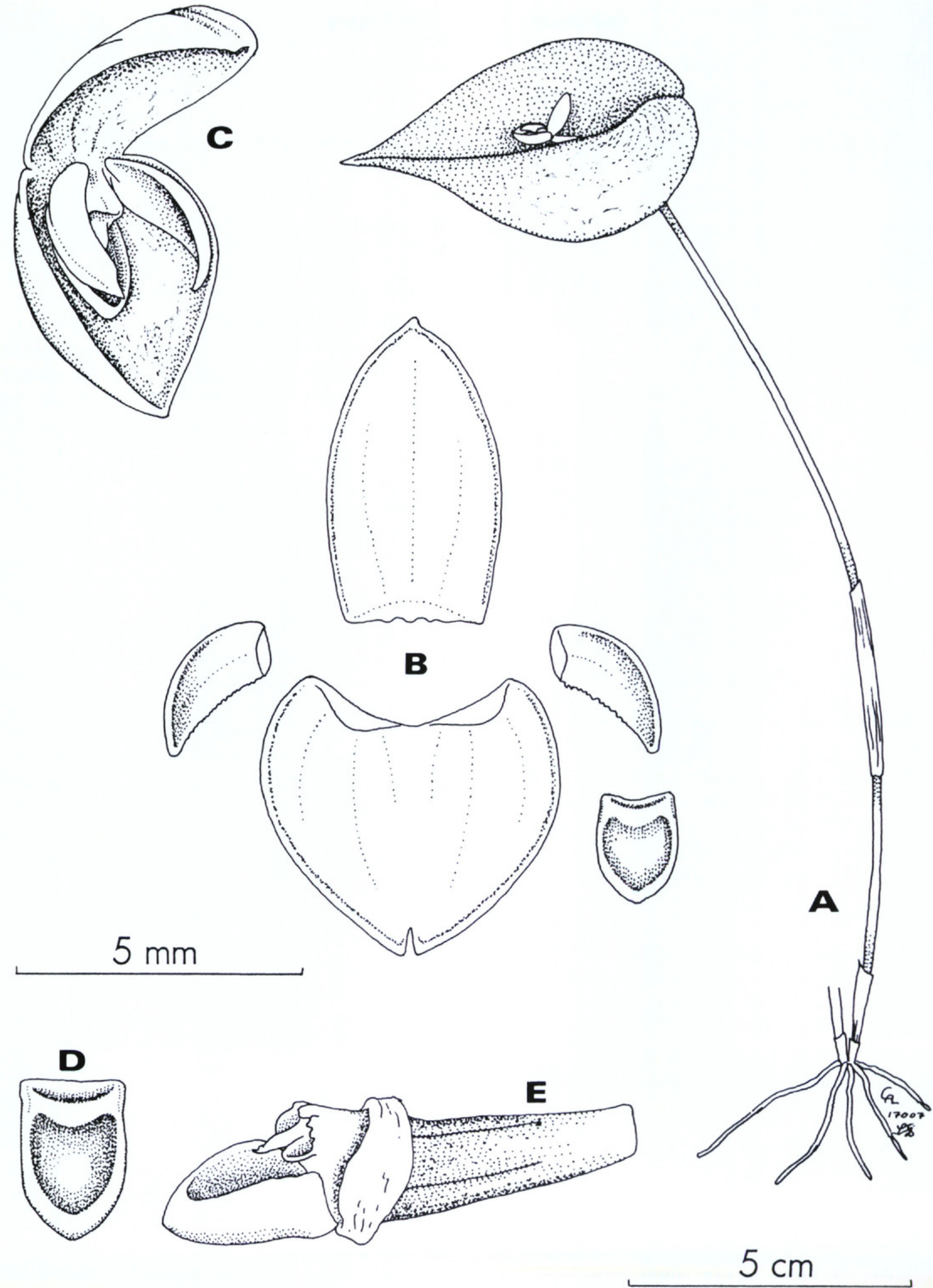

$3 \mathrm{~mm}$

Figure 6. Pleurothallis loreae Carnevali \& I. Ramírez. - A. Habit. - B. Floral segments flattened. -C. Flower in natural position. -D. Labellum. - E. Column with labellum attached. (Based on the holotype, G. Carnevali et al. 3263, CICY, VEN.) Drawing courtesy of C. A. Luer, sketch \#17007. 
minutely crenate-denticulate, 1-nerved; labellum $1.9-2.1 \times 1.2-1.4 \mathrm{~mm}$, thick, oblong-ovate in general outline, apically rounded to broadly obtuse, with a central depression, with a transversal ridge near base below which it is shallowly concave; column 1.2-1.4 mm long, proportionally short as compared to labellum.

Etymology. Named after Francisco Lorea Hernández, curator at the herbarium of the Instituto de Ecología, A.C., Xalapa, Mexico (XAL), and a specialist in the Lauraceae, who participated in the collection of the type specimen.

This species is vegetatively identical to Pleurothallis cordata (Ruiz \& Pavón) Lindley, a taxon widespread from Bolivia to Venezuela. In the new species, however, the petals are thicker, falcate, glabrous, and the labellum is ventrally concave. Florally and vegetatively it seems closest to $P$. chama Luer, known from Ecuador. The Ecuadorian species is a much larger plant (stems to $19 \mathrm{~cm}$ long in $P$. loreae vs. up to $20-35 \mathrm{~cm}$ in $P$. chama) with larger flowers (dorsal sepal $5.5 \mathrm{~mm}$ long in $P$. loreae vs. $12 \mathrm{~mm}$ long in $P$. chama), featuring a 7 -nerved dorsal sepal (vs. 3-nerved in P. loreae), and a flat or convex, papillose labellum (vs. deeply concave, glabrous in $P$. loreae).

Pleurothallis loreae is one of several distinctive endemic orchids of the Sierra de San Luis in northwestern Venezuela. Other endemics occurring there include Masdevallia garciae Luer, Pleurothallis sanluisii Foldats, Pleurothallis transversilabia Carnevali \& I. Ramírez, Prosthechea garciana (Garay \& Dunsterville) W. Higgins, Stelis sanluisensis Foldats, and several other still undescribed orchid taxa.

Pleurothallis escalerensis Carnevali \& C. A. Luer, sp. nov. TYPE: Venezuela. Bolívar: carretera El Dorado-Santa Elena de Uairén, km 95 al S of El Dorado, light forest over granitic outcrops, 300-400 m, 20 June 1994, G. Carnevali, W. Fritz \& C. Coleman 3672 (holotype, VEN [EtOH]). Figure 7.

Species haec Pleurothalli barbulatae similis, sed inflorescentia multilongiore, rachi laxiore, labello glabro, trilobato, lobis lateralibus falcatis, truncatis, praemorsis recedit.

Minute, shortly creeping epiphyte, $2.5-3.5 \mathrm{~cm}$ tall counting the inflorescences; stems $2-3 \mathrm{~mm}$ long, clothed by 1 or 2 scarious sheaths; leaves 9 $11 \mathrm{~mm}$ long, ca. $3 \mathrm{~mm}$ wide, coriaceous, spathulate, rounded to broadly obtuse apically, basally attenuate into a short pseudopetiole ca. $1 \mathrm{~mm}$ long; inflorescences 17-27 mm long, much surpassing the subtending leaf, erect, successively 4- to 11-flowered, rachis somewhat zigzag; pedicels $1-1.5 \mathrm{~mm}$ long, ovary ca. $0.75 \mathrm{~mm}$ long, flowers resupinate, campanulate, pale hyaline purple with darker nerves; dorsal sepal 2.4-2.6 mm long, ca. $1.5 \mathrm{~mm}$ wide, lanceolate, acute, 3-nerved; lateral sepals fused for more than $3 / 4$ of their length into an elliptic synsepal $2.5-2.6 \mathrm{~mm}$ long, ca. $2 \mathrm{~mm}$ wide, the synsepal concave, at base forming a shallow mentum (a conspicuous, somewhat chin-like convexity seen from below at the base of the synsepal), apically somewhat deflexed; petals 1.9-2.1 mm long, elliptic-rhomboid, obliquely deflexed, acuminate, 1nerved; labellum 3-lobed just below the middle, $1.7-1.9 \mathrm{~mm}$ long, $1-1.1 \mathrm{~mm}$ wide across the spread lateral lobes, central lobe 0.9-1.1 $\times 0.5-0.55 \mathrm{~mm}$, oblong-lanceolate, margins smooth, the apex somewhat deflexed, lateral lobes ca. $0.25 \mathrm{~mm}$ long and wide, erect in natural position, porrect, sub-triangular, the apex truncate, the margins erose-fimbriate, the disk with a longitudinal depression reaching to ca. 5/6 of the total length of the labellum, the truncate base hinged to the column foot, with a pair of retrorse basal lobules; column 1.4-1.6 mm long, apically with a pair of broad smooth wings, the clinandrium irregularly 3-dentate, the foot ca. $0.8 \mathrm{~mm}$ wide.

This new taxon belongs in Pleurothallis subg. Specklinia sect. Muscosae Lindley, as circumscribed by Luer (1986). If the recent classification by Pridgeon and Chase (2001) were followed, this species would fall within the circumscription of $\mathrm{An}$ athallis Barbosa Rodriguez. This complex includes, among others, the following species in the Venezuelan Guayana: P. aondae Carnevali \& G. Romero, P. barbulata Lindley, P. hilariana Carnevali \& G. Romero, $P$. minima C. Schweinfurth, P. steinbuchiae Carnevali \& G. A. Romero, and now the novelty here proposed. Among the many taxa of section Muscosae, Pleurothallis escalerensis is close to $P$. barbulata and $P$. aondae, but in those species the labellum is simple, thus lacking the subtriangular lateral lobes; these two species also have an abbreviated, straight rachis, condensed within several large bracts or spathes, which are otherwise absent in this novelty. The general aspect of leaves and inflorescence suggests a relationship with Pleurothallis cuspidata Luer, found from Panama to Ecuador, but in this species all perianth segments are long acuminate and the plants are conspicuously larger (with leaves 3-4 cm long vs. 0.9-1.1 mm long in P. escalerensis).

Pleurothallis escalerensis is apparently rare, having been found only once in a relatively well-col- 

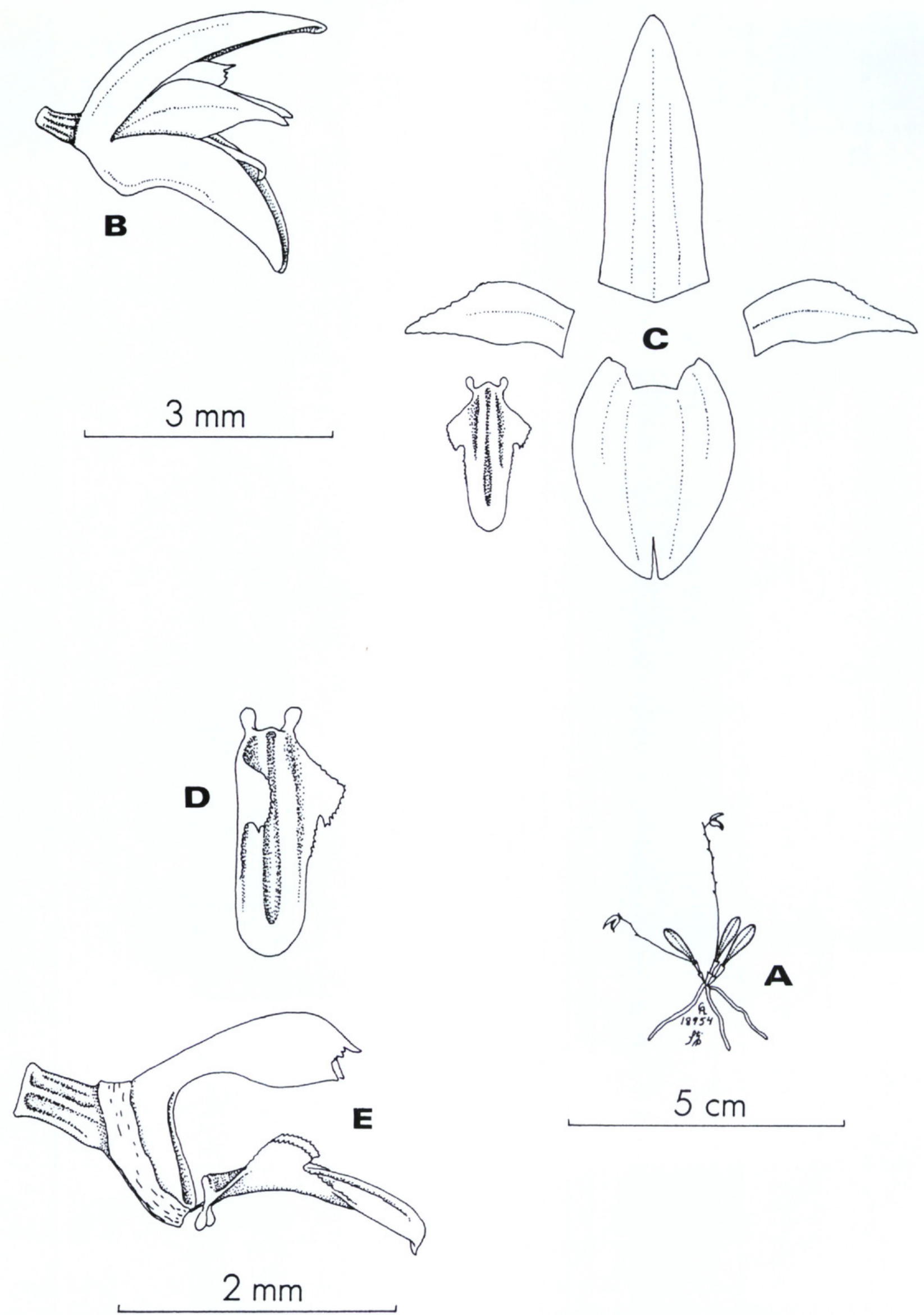

Figure 7. Pleurothallis escalerensis Carnevali \& C. A. Luer. - A. Habit. - B. Flower in natural position. - C. Floral segments flattened. - D. Labellum. - E. Column with labellum attached. (Based on the holotype, G. Carnevali et al. 3672, VEN.) Drawing courtesy of C. A. Luer, sketch \#18954. 




Figure 8. Pleurothallis stellata I. Ramírez \& Carnevali. - A. Habit. - B. Foliar apex. - C. Detail of open flower, showing labellum and column. - D. Floral segments flattened. - E. Labellum. - F. Details of column, labellum, and anther. -G. Anther and pollinia. (Based on holotype, G. C. K. Dunsterville 610, A MES.) Drawing by G. C. K. Dunsterville, sketch \#610.

lected area in Venezuela. It may have been overlooked due to its diminutive size. This species was included as "Pleurothallis sp. A" in the Pleurothallis treatment of the Flora of the Venezuelan Guayana (Carnevali \& Ramírez in Carnevali et al.,
2003: 523). The type locality, i.e., the lower slopes of the Escalera in northeastern Bolívar state at $200-500 \mathrm{~m}$, is a place of high orchid diversity. Here a mixture of tepui species meet their lower altitudinal ranges and grow along with taxa asso- 
Table 1. A comparison of Pleurothallis stellata and P. index.

\begin{tabular}{|c|c|c|}
\hline Feature & Pleurothallis stellata & Pleurothallis index \\
\hline Leaf shape & narrowly ovate & ovate \\
\hline Leaf base & with non-overlapping basal lobes & basal lobes overlapping for $1 \mathrm{~cm}$ or more \\
\hline Leaf dimensions and proportions & $9 \times 2.5 \mathrm{~cm} ; \mathrm{w} / \mathrm{l}=0.27$ & $5.5 / 3 ; \mathrm{w} / \mathrm{l}=0.557 .5 / 3.8 ; \mathrm{w} / \mathrm{l}=0.50$ \\
\hline Structure subtending inflorescence & a horizontal sheath $2 \mathrm{~cm}$ long & $\begin{array}{l}\text { a suberect spathe } 12-18 \mathrm{~mm} \text { long, } 5 \mathrm{~mm} \\
\text { wide (as in } P \text {. cardiostola) }\end{array}$ \\
\hline Dorsal sepal & $12 \times 6 \mathrm{~mm} ; \mathrm{w} / \mathrm{l}=0.5$ & $16 \times 4 \mathrm{~mm} ; \mathrm{w} / \mathrm{l}=0.25$ \\
\hline Synsepal & $12 \times 5 \mathrm{~mm} ; \mathrm{w} / \mathrm{l}=0.41$ & $16 \times 4 \mathrm{~mm} ; \mathrm{w} / \mathrm{l}=0.25$ \\
\hline Petals & $8.5 \times 1.8 \mathrm{~mm} ; \mathrm{w} / \mathrm{l}=0.21$ & $15 \times 2.2 \mathrm{~mm} ; \mathrm{w} / \mathrm{l}=0.14$ \\
\hline Labellum & $2 \times 2 \mathrm{~mm} ; \mathrm{w} / \mathrm{l}=1$ & $4.5 \times 2 \mathrm{~mm} ; \mathrm{w} / \mathrm{l}=0.45$ \\
\hline Labellum shape & $\begin{array}{l}\text { ovate, sub 3-lobed, obtuse to } \\
\text { rounded }\end{array}$ & ovate triangular, acute \\
\hline
\end{tabular}

ciated with sandstone and granitic outcrops as well as other taxa from lowland Guianan forests. Orchids include Brassia bidens Lindley, Catasetum barbatum (Lindley) Lindley, Catasetum discolor (Lindley) Lindley, Braemia vittata (Lindley) Jenny, Chaubardiella tigrina (Garay \& Dunsterville) Garay, Galeottia jorisiana (Rolfe) Schlechter, and many others, including not fewer than 10 distinct Octomeria species.

Etymology. The name refers to the only locality where this novelty is known, the ascent to Cerro Venamo, along the road from El Dorado to Santa Elena de Uairén, in Bolívar State, Venezuela. The topography is steep and broken on this ascent and so is the road, thus being commonly known as La Escalera, "the stairway."

Pleurothallis stellata I. Ramírez \& Carnevali, sp. nov. TYPE: Venezuela. Distrito Federal: tall cloud forest at ca. $4500 \mathrm{ft}$., above El Limón, Mar. 1961, G. C. K. Dunsterville 610 (holotype, AMES). Figure 8.

Pleurothallis haec $P$. indice affinis sed foliis proportione angustioribus auriculis minoribus, spathis non obovatis nec suberectis, synsepalo quam sepalo postico angustiore, sepalis petalisque proportione latioribus, labello subtrilobato obtuso discrepat.

Epiphytic, cespitose herbs; rhizome abbreviated; stems erect, terete, $10-12 \mathrm{~cm}$ long, bearing 2 thin, close-fitting sheaths below the middle; leaves 7-9 $\mathrm{cm}$ long, $2.0-2.5 \mathrm{~cm}$ wide, narrowly ovate to lanceolate, acute, thin but fairly rigid; inflorescences of a single flower borne in succession from a graybrown, horizontal, ca. $2 \mathrm{~cm}$ long sheath at base of leaf; pedicels ca. $10 \mathrm{~mm}$ long, ovary ca. $3 \mathrm{~mm}$ long; flowers subfleshy, resupinate, widely spreading (thus flower stellate), relatively showy for the section, sepals and petals deep, rich, very beautiful "wine-purple" (fide type), with veins of sepals (par- ticularly dorsal sepal) showing up in even darker color, all inner surfaces covered with microscopic short glandular projections, rather too short to be called hairs (fide type, ex schedulae); dorsal sepal $12 \times 6 \mathrm{~mm}$, narrowly ovate, acuminate, acute, 5nerved; lateral sepals totally connate into a lanceolate synsepal $12 \times 5 \mathrm{~mm}$, acute, acuminate, 6nerved; petals $8.4-8.6 \times 1.7-1.9 \mathrm{~mm}$, narrowly elliptic, acuminate, thick and fleshy at base, margins finely ciliate, 1-nerved; labellum 1.9-2 mm long, 1.9-2 mm wide when spread, fleshy, dark wine purple, surface finely glandular, ovate-triangular, somewhat 3-lobed, obtuse to rounded, with a transverse ridge at base, flexibly attached to column, glenion well-developed; column 1.4-1.6 mm long, stout, oblongoid, dorsoventrally depressed, puce-colored, stigmatic surfaces two, elliptic, shiny; rostellum acicular; anther creamy white; pollinia 2, hard, yellow.

Etymology. The name refers to the stellate aspect of the flower, which is due to the relatively similar shapes of the widely spreading dorsal sepal, synsepal, and petals.

This showy new species is superficially reminiscent of the Colombian species Pleurothallis index Luer. However, Pleurothallis stellata differs from $P$. index in a number of features, especially the lack of the suberect spathe. In addition, the large, overlapping basal lobes found in the leaves of $P$. index are much reduced and non-overlapping in the Venezuelan $P$. stellata. Moreover, the generally smaller, differently proportioned flowers of $P$. stellata are distinct. In particular, the labella of the two taxa are very different. See Table 1 for a comparison of the two species.

Acknowledgments. The authors are grateful to Carl A. Luer, Bruno Manara, Rossana Marrufo, and Carlos Yam for the line drawings, to the curators of 
the herbaria cited herein for their assistance, and to Gustavo A. Romero for informative discussions and for his editorial help.

\section{Literature Cited}

Carnevali, G., I. Ramírez-Morillo, G. Romero-González, C. Vargas \& E. Foldats. 2003. Orchidaceae. Pp. 200-765 in P. Berry, K. Yatskievych \& B. Holst (editors), Flora of the Venezuelan Guayana, Vol. 7. Missouri Botanical Garden Press, St. Louis.

Christenson, E. A. 1996. Notes on Neotropical Orchidaceae-II. Lindleyana 11: 12-26.

Couret, P. 1982. Jewels of the Venezuelan Orchids. Librería Alemana Oscar Todtmann, Caracas, Venezuela.

Dunsterville, G. C. K. \& L. A. Garay. 1979. Orchids of Venezuela, An Illustrated Field Guide, A-G. Botanical
Museum, Harvard Univ. Printing, Cambridge, Massachusetts.

Greuter, W., J. McNeill, F. R. Barrie, H. M. Burdet, V. Demoulin, T. S. Filgueiras, D. H. Nicolson, P. C. Silva, J. E. Skog, P. Trehane, N. J. Turland \& D. L. Hawksworth (editors). 2000. International Code of Botanical Nomenclature (Saint Louis Code). Regnum Veg. 138.

Hágsater, E. \& C. H. Dodson. 1993. Epidendrum thermophilum Hágs. \& Dodson, in E. Hágsater \& G. Salazar (editors), Icon. Orchid. 2: 193.

Luer, C. A. 1986. Icones Pleurothallidinarum III. Systematics of Pleurothallis (Orchidaceae). Monogr. Syst. Bot. Missouri Bot. Gard. 20.

Pridgeon, A. M. \& M. K. Chase. 2001. A phylogenetic reclassification of Pleurothallidinae (Orchidaceae). Lindleyana 10: 235-271.

Romero, G. A. 1997. Venezuela, Paraiso de Orquídeas. Armitano eds. Caracas, Venezuela. 


\section{$2 \mathrm{BHL}$ Biodiversity Heritage Library}

Carnevali Fernández-Concha, Germán and Ramírez-Morillo, Ivón M. 2003. "Nomenclatural novelties in the Orchidaceae from Venezuela and Guyana." Novon a journal of botanical nomenclature from the Missouri Botanical Garden 13, 405-418. https://doi.org/10.2307/3393371.

View This Item Online: $\underline{\text { https://www.biodiversitylibrary.org/item/14673 }}$

DOI: https://doi.org/10.2307/3393371

Permalink: https://www.biodiversitylibrary.org/partpdf/25174

\section{Holding Institution}

Missouri Botanical Garden, Peter H. Raven Library

\section{Sponsored by}

Missouri Botanical Garden

\section{Copyright \& Reuse}

Copyright Status: In copyright. Digitized with the permission of the rights holder.

License: http://creativecommons.org/licenses/by-nc-sa/3.0/

Rights: https://biodiversitylibrary.org/permissions

This document was created from content at the Biodiversity Heritage Library, the world's largest open access digital library for biodiversity literature and archives. Visit BHL at https://www.biodiversitylibrary.org. 